\title{
Factors Influencing Deposit Mobilization: A Study on Commercial Bank of Ethiopia
}

\author{
Addisalem Tadesse Bogale \\ Lecturer of Business Administration and Information System (BAIS) Department, \\ College of Business and Economics, Ambo University, Woliso campus \\ Tagesse Abebe Sugebo \\ Manager Batena Branch, Commercial Bank of Ethiopia \\ Lemabo Jaboro Satore \\ Lecturer of Management department at Rift valley university Hossana campus
}

\begin{abstract}
The study had looked at the potential of the country regarding deposit mobilization by taking CBE as evidence. The study used time serious secondary data to be collected from Commercial Bank of Ethiopia data base. The study had found variables that can affect the total deposit of commercial banks. Eight variables are regressed with the dependent variable, i.e. total deposit; these variables include Total Loans and Advances, Total Revenue, Total Expense, liquidity, Total Asset, Consumer Price Index, and Operating Expense. The analysis techniques have been chosen suiting the study's objectives and nature of variables. All these variables are tested using Eviews 20.0 software VAR model. The result of Johansson co-integration test with lags in level shows in the long run Reserve Requirement and Consumer Price Index are negatively affect the Total Deposit in Commercial Bank of Ethiopia whereas the Total Asset, Total Liability and Total Loans and Advance affect Commercial Bank of Ethiopia`s Deposit positively and all are statically significant. Once the variables are co integrated we used the vector error correction (VECM) to determine the short run coefficient. And In the short run, among the given Determinants of Commercial Bank Deposit only Consumer Price Index and The total Loans and Advance are significant and affect the Deposit in Commercial Bank of Ethiopia negatively. Finally the study had recommended what should be done to mobilize more deposits.
\end{abstract}

Keywords: Income, Expense, Asset, Liability, Reserve, Loan and Consumer price index

DOI: $10.7176 / \mathrm{JESD} / 12-1-06$

Publication date: January $31^{\text {st }} 2021$

\section{Introduction}

Herald (2009) states deposits are the main source of banks to provide loan. This deposit is mainly provided by peoples. However deposits can also be provided by business organizations, NGOs, government and so on. Therefore, whether deposits are from individuals, businesses and government they are important financial source of banks (Mohammad and Mahdi, 2010).

Ethiopian government launches a five years transformation and growth plan to make middle class country (CBE, August 2012). Moreover, the government strives to attain the Millennium Development Goals (MDG) in the year 2025. As a result, the government is committed to implement intensive mega projects including the Ethiopian Renaissance Millennium Dam with its own resources. Accordingly the financial sectors in general and $\mathrm{CBE}$ in particular have been given to mobilize a huge amount of deposit and foreign currency so as to make the aforementioned projects and plan materialized.

The Commercial Bank of Ethiopia (CBE) has aggressively expanded its presence in all directions of the country and currently it has more than 1456 branches administrated by 15 District Offices, spanning the entire breadth and width of the country. The leading African bank with assets of 711.96 billion Birr as on June 30, 2019. Despite the flourishing of private commercial banks, CBE has remained in the lead in terms of assets, deposits, capital, customer base, and branch networks (CBE, 2019).

Commercial banks are profitable financial institutions that give financial service to the body in need of the service. They accept money from the depositors and lend it to the borrowers. Thus for commercial banks to lend, there have to be deposits in their treasury. According to Mohammad and Mahdi (2010) financial resources of banking system are naturally provided from people's deposit. Therefore, we can say that deposits are the most important resource of commercial banks.

\section{Statement of the problem}

In Ethiopia as far as the knowledge of the researchers is concerned, there are very few researches related to determinants of commercial banks deposit. Furthermore, those conducted a study on determinants of commercial bank deposit of single Ethiopian government bank only, which is Commercial Bank of Ethiopia. All of the three 
researches are conducted only by taking one government bank but this research is quite different in its industry selection, type of data and incorporates the commercial bank deposit variable. As there is no comprehensive study on the various determining factors of deposit in the country, this study is filling the research gap by incorporating a more complete list of variable determining the factors that affect commercial banks deposit in Ethiopia.

\section{Research Hypotheses}

In order to answer the research question study, literatures review of previous studies were conducted to drive the hypothesis based on existing knowledge and the following seven hypotheses were developed for this research, that are:

H1: Income in commercial bank of Ethiopia has significant and positive impacts on commercial bank of Ethiopia Deposit

H2: Expense in commercial bank of Ethiopia has significant and positive impacts on commercial bank of Ethiopia Deposit

H3: Asset in commercial bank of Ethiopia has significant and positive impacts on commercial bank of Ethiopia Deposit

H4: Liability commercial bank of Ethiopia has significant and positive impacts on commercial bank of Ethiopia Deposit

H5: Reserve in commercial bank of Ethiopia has significant and positive impacts on commercial bank of Ethiopia Deposit

H6: Loan Advance commercial bank of Ethiopia has significant and positive impacts on commercial bank of Ethiopia Deposit

H7: Consumer price index in Ethiopia has significant and positive impacts on commercial bank of Ethiopia Deposit

\section{Literature Review}

The Factors Affecting Commercial Banks Deposits An important indicator of the success and efficiency of any credit agency, which is also a banking institution is, the extent to which it is able to mobilize the savings of the community in the form of deposit. But deposit mobilization is very difficult task. It depends up on exogenous as well as endogenous factors (Desinga, 1975).

\section{Exogenous Factors}

These are factors that are from country and banks that can affect the growth of commercial banks deposits. There are discussed as follows:-

\section{- Country Specific Factors}

The country's economic, social and political factors can affect the commercial banks. According to Herald and Heiko (2009), country specific risks such as political, economic and financial risks may affect the propensity for depositors to place funds in the banking system. Any single bank operates under the rule and regulation of the country where it belongs, also different problems and shocks that has happened in the country has its own concern in the banks operation. Generally, banks' success in their operation is mainly depends on the environment where the business is undertaken.

\section{- Saving interest rate (Deposit rate)}

One of the most effective factors for deciding to deposit in banking system is the interest rate (Mohammad and Mahdi, 2010). Moreover, this article shows the impact of interest rate on the performance of the banking system to achieve the goals that are expected from the banking system. Herald and Heiko (2009) also mentioned interest as one of the determining factor for commercial banks deposits.

\section{- Inflation}

As to Herald and Heiko (2009), inflation is one of the factors that determine commercial banks deposits. Fischer showed that in Latin America the effect of inflation on savings and time deposit to GDP was significantly negative (Mohammad and Mahdi, 2010). The classical belief is that, because bank assets and liabilities are expressed in monetary terms and because these assets will normally grow in line with growth in money supply, banks are relatively immune from the effects of inflation (Devinaga, 2010).

\section{- Real Interest Rate}

Real interest rate is nominal interest rate minus inflation rate. Mohammad and Mahdi (2010) said that in negative real interest rate condition, people withdraw their resources from banking system. According to Mohammad and Mahdi (2010), research supposed that decrease in real interest rate could decrease true demands for money (in its extensive definition including savings and time deposits). Therefore it states that the interest rate and deposit of the banks have positive relationship.

\section{- Population growth of the country}

The twin objectives of commercial banks, i.e. acquiring deposits and advancing credit cannot be attained without good banking habits of the people (Mahendra, 2005). Moreover Mahendra (2005) states that, the number of deposit 
accounts is more important because it ensures that the probability of account is more important because it ensures that the probability of account holders withdrawing cash at a time decreases as the number of deposit account increase, thereby creating advantage for banks in terms of increasing the size of the loanable fund. So the higher number of deposit accounts the greater is the advantage to banks. The number of deposit accounts depends on the number of deposit account holders.

\section{- Per capita income of the society}

According to Jim (2008), per capita is the level of GDP divided by the population of a country or region. Changes in real GDP per capita over time are often interpreted as a measure of changes in the average standard of living of a country. If households and firms desire to hold more money, deposits will increase (Evan, 2006). So, the relationship between income and deposits is positive; that is as the income of the society increases, the commercial bank' deposits increase. Income is expected to have a positive effect on deposits (Baqui et al, 1987). Therefore as society's per capita income increases the same will happen for commercial banks deposits. Mahendra (2005) also indicates that income of the society matters for banks' deposit growth. Eshetu and Mammo (2009), Ethiopia is one of the poorest countries in the world with an estimated per capita income of just \$203 (IMF 2007 cited by the Financial Standards Foundation).

- Macroeconomic Highlights

- Consumer price index

According to Herald and Heiko (2009), price can also determine commercial bank deposit and it can be indicated by consumer price index.

\section{Bank Sector Factors}

\section{$\checkmark \quad$ Liquidity of the banks}

The concept of liquidity in finance principally lies in two areas (Ismal, 2010): liquidity of financial instruments in the financial market and the liquidity related to solvency. The former related to liquid financial markets and financial instruments, smooth transactions and no barriers. The latter discusses the obligation of banks to make payments to third parties (Fiedler, 2000). Some examples of this includes: setting up liquidity management policies, reserve liquidity, balancing assets and liabilities and preparing liquid financial instruments (Ismal, 2010).

\section{$\checkmark \quad$ Profitability of the bank}

Erna and Ekki (2004) find the long run relationship between commercial banks deposits and the profitability of the banks. Higher bank profits would tend to signal increased bank soundness, which could make it easier for these banks to attract deposits (Herald and Heiko, 2009). However, the effect of bank profitability and bank size are found to be insignificant once controlling for the other variables. So, the effect of profitability and banks size on commercial bank deposit is lower as compared with other variables.

\section{$\checkmark$ Bank size}

Among the factors prominently identified as affecting deposit variability one is bank size. Evidence indicates that the number and diversity of the ownership of individual deposit accounts as well as the distribution of deposits by type vary with bank size(George, 1972).

\section{$\checkmark \quad$ Transaction cost}

Important indicator of management's effectiveness in any bank are whether or not deposited funds have been raised at the lowest possible cost and whether enough deposits are available to fund those loans the bank wishes to make(Mahendra, 2005). This last point highlights the two key issues that every bank must deal with in managing its deposits(Mahendra, 2005):- Where can the bank raise funds at the lowest possible cost. How can management ensure that every bank always has enough deposits to support the volume of loans and other financial services demanded by the public.

\section{Conceptual framework}

The conceptual framework indicates the crucial process, which is useful to show the direction of the study 


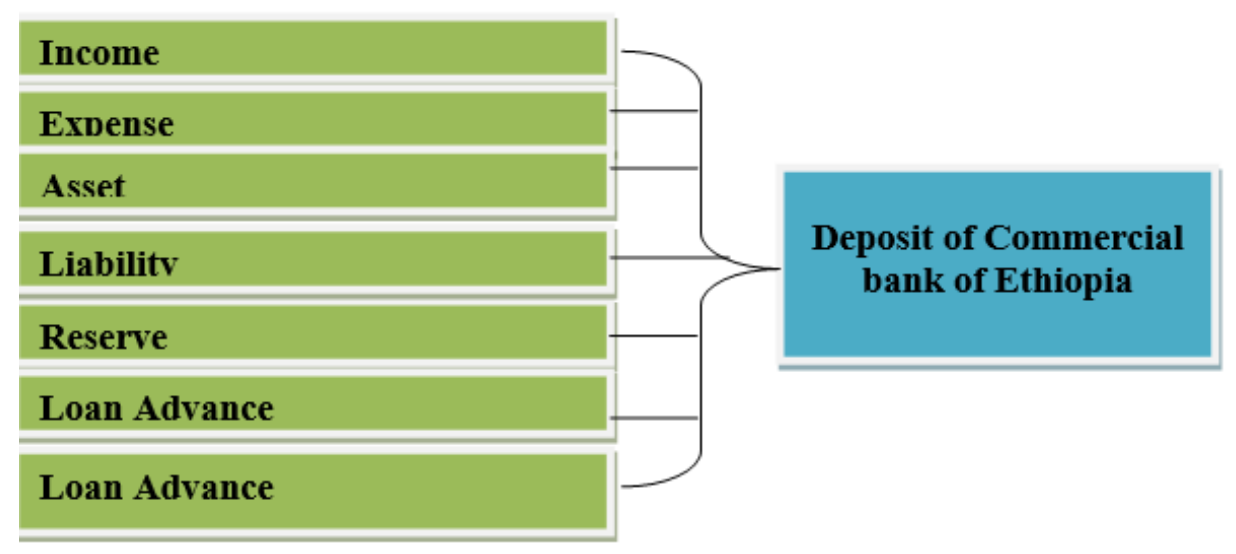

Figure 1: conceptual framework Source: Developed by the researcher

\section{Methodology of the Study}

Empirical methodology is applied to address the purpose of the research mentioned in the research question. Since VAR is considered as an instrument for estimating the model since it includes all empirical tools used to get more precise results within given data for research purpose,. There are some prerequisites dealing with data before realizing VAR models that should be implemented. First, time series included in VAR model have to be stationary. Therefore, unit root test is applied. The test primarily utilizes Augmented Dickey Fuller (ADF). Secondly, the appropriate lag length is determined. And then co integration test, VECM, Granger causality test, Variance Decompositions and finally stability test follows.

\section{Functional Relation and Model specification}

Functional relationship

The functional relation and the expected signs of dependent variable, Deposit in commercial Bank of Ethiopia and its independent variable

$$
\begin{aligned}
& \text { TD = F (TI TE TA TL TR TLA CPI }) \\
& \text { Where: } \\
& \text { TD = Total commercial bank of Ethiopia Deposit } \\
& \text { TI = Total Income in commercial bank of Ethiopia } \\
& \text { TE = Total expense in commercial bank of Ethiopia } \\
& \text { TA = Total asset in commercial bank of Ethiopia } \\
& \text { TL= total Liability commercial bank of Ethiopia } \\
& \text { TR= Total Reserve in commercial bank of Ethiopia } \\
& \text { TLA = total Loan Advance commercial bank of Ethiopia } \\
& \text { CPI = consumer price index in Ethiopia }
\end{aligned}
$$

\section{Model specification}

Specification of the Econometric VAR model

At the beginning we transformed all the variables under study into Log data to avoid hetroscedasticity and to show elasticity of the variables. Then, the econometric VAR model is specified as the unstructured VAR model.

$\log ($ TD $)=\beta_{0}+\beta_{i 1} \log (\text { TI) })_{t-i}+\beta_{i} 2 \log (\text { TE })_{t-i}+\beta_{i 3} \log (\text { TA })_{t-i}+\beta_{i 4} \operatorname{og}(\text { TL })_{t-i}+\beta_{i 5} \log ($ TR $)+\beta_{i 6} \log ($ TLA $)+\beta_{i 7}$ $\log (\mathrm{CPI})+\varepsilon 1 t$....................equation (1)

Where,

$\beta_{\mathrm{i}}$ and are coefficients of $1 x \mathrm{k}$ matrix to be estimated

$i=1 . . . . . . . . . . . . . ., k$ k the VAR order

$\boldsymbol{\varepsilon}_{1 \mathrm{t}}=$ the error term

Log $=$ logarithms of the variables.

The model is linear in the parameters but non-linear in the variables. $\beta_{\mathrm{i} 1 \ldots \ldots \ldots . . .} \boldsymbol{\beta}_{\mathrm{i} 7}$ Coefficients are semi-elasticity and $\boldsymbol{\varepsilon}_{\mathbf{1}}$ is stochastic disturbance term with standard properties. The sign of each coefficient is dependent upon the relative contributions of the corresponding explanatory variables which in turn depend on the functioning of the economic system under consideration.

Specification of Vector Error Correction Model

In line with equation (4.1) the error correction model is: $\Delta \log (\mathrm{TD})=\mathbf{\Omega}\left(\beta_{1} \log (\mathrm{TI})_{\mathrm{t}-1}-\beta_{2} \log (\mathrm{TE})_{\mathrm{t}-1}\right)+\beta_{4} \log (\mathrm{TA})_{\mathrm{t}-1} \beta_{5} \log (\mathrm{TL})_{\mathrm{t}-1} \beta_{6} \log (\mathrm{TR})_{\mathrm{t}-1} \beta_{7} \log (\mathrm{TLA})+\beta_{8} \log$ 
$(\mathrm{CPI})_{\mathrm{t}-1+{ }_{+} \mathrm{C}-}\left[+\beta_{9} \Delta \log (\mathrm{TD})_{\mathrm{t}-\mathrm{I}}+\beta_{10} \Delta \log (\mathrm{TI})_{\mathrm{t}-\mathrm{I}}+\beta_{12} \Delta \log (\mathrm{TE})_{\mathrm{t}-\mathrm{I}}+\beta_{13} \Delta \log (\mathrm{TA})_{\mathrm{t}-\mathrm{I}}+\beta_{14} \Delta \log (\mathrm{TL})_{\mathrm{t}-\mathrm{I}}\right.$ $\left.+\beta_{15} \Delta \log (\mathrm{TR})_{\mathrm{t}-\mathrm{I}}+\beta_{16} \Delta \log (\mathrm{TLA})_{\mathrm{t}-\mathrm{I}}+\beta_{17} \Delta \log (\mathrm{CPI})_{\mathrm{t}-\mathrm{I}}\right] \boldsymbol{\varepsilon}_{1} \ldots . . .$. equation (2)

Where:

$\mathbf{\Omega}$ is the speed of adjustment term or the coefficient of the error term

$\beta_{5} \ldots \ldots \ldots \ldots \ldots . . . . . . . \beta_{17}$ are $1 \mathrm{X} \mathrm{K}$ matrix of short run coefficients to be estimated

$\mathrm{I}=1,2,3 \ldots$ where $\mathrm{k}$ is lag order

$\boldsymbol{\varepsilon}_{\mathbf{t}}$ is vector of exogenous shocks

\section{Discussion and Estimation result}

\section{Johansson co integration equation}

To identify the determinant of saving mobilization in commercial bank of Ethiopia, The Johansen procedure with lags in level was used to test the existence co-integration among variables. The test statistics (trace static and maximum Eigen values) results are presented in table shows the rank of co-integration.

Lag selection criterions like sequential modified likelihood ratio (LR), Final prediction error (FPE), Aikaike information criterion (AIK), Schwarz information criterion (SC) and Hannan-Quinn information criterion (HQ) suggest an optimal lag length of one which has been used in our analysis. Results of these criterions are reported in table.

\section{Optimal lag length}

Table 1: VAR Lag Order Selection Criteria

Endogenous variables: LOG(TD) LOG(TI) LOG(TE) LOG(TA) LOG(TL) LOG(TR) LOG(TLA) LOG(CPI)

Exogenous variables: $\mathrm{C}$

Included observations: 27

\begin{tabular}{lllllll}
\hline \hline Lag & LogL & LR & FPE & AIC & SC & HQ \\
\hline \hline 0 & 150.6966 & NA & $3.55 \mathrm{e}-15$ & -10.57012 & -10.18617 & -10.45595 \\
1 & 345.4260 & 259.6392 & $2.73 \mathrm{e}-19$ & -20.25378 & -16.79822 & -19.22626 \\
2 & 491.4127 & $108.1382^{*}$ & $3.01 \mathrm{e}-21^{*}$ & $-26.32686^{*}$ & $-19.79969^{*}$ & $-24.38599^{*}$ \\
\hline \hline
\end{tabular}

* indicates lag order selected by the criterion

LR: sequential modified LR test statistic (each test at 5\% level)

FPE: Final prediction error

AIC: Akaike information criterion

$\mathrm{SC}$ : Schwarz information criterion

HQ: Hannan-Quinn information criterion

Source: Survey result, 2019

Co-integration among the variables

As the variables have same order of integration, therefore Johansen co integration can be applied to find the longrun relationship of fiscal policy and real domestic product in Ethiopia, and all its determinants of independent variables. The results of Johansen's co integration test have been reported in table. And the appropriate lag length selected that seen the above table. 


\section{Co-integration test}

Series: LOG(TD) LOG(TI) LOG(TE) LOG(TA) LOG(TL) LOG(TR) LOG(TLA) LOG(CPI)

Lags interval (in first differences): 1 to 1

Table 2: Co- Integration test

Unrestricted Cointegration Rank Test (Trace)

\begin{tabular}{lllll}
\hline \hline $\begin{array}{l}\text { Hypothesized } \\
\text { No. of CE(s) }\end{array}$ & Eigenvalue & $\begin{array}{l}\text { Trace } \\
\text { Statistic }\end{array}$ & $\begin{array}{l}0.05 \\
\text { Critical Value }\end{array}$ & Prob. $^{* *}$ \\
\hline \hline None * & 0.963211 & 338.2555 & 159.5297 & 0.0000 \\
At most 1 & 0.949602 & 249.0863 & 125.6154 & 0.0000 \\
At most 2* & 0.930711 & 168.4156 & 95.75366 & 0.0000 \\
At most 3* & 0.774582 & 96.33991 & 69.81889 & 0.0001 \\
At most 4 & 0.644631 & 56.11538 & 47.85613 & 0.0069 \\
At most 5 & 0.427526 & 28.18125 & 29.79707 & 0.0759 \\
At most 6 & 0.248101 & 13.12099 & 15.49471 & 0.1104 \\
At most 7* & 0.181931 & 5.421839 & 3.841466 & 0.0199 \\
\hline \hline
\end{tabular}

Trace test indicates 5 cointegrating eqn(s) at the 0.05 level

* denotes rejection of the hypothesis at the 0.05 level

**MacKinnon-Haug-Michelis (1999) p-values

Unrestricted Cointegration Rank Test (Maximum Eigenvalue)

\begin{tabular}{lllll}
\hline \hline $\begin{array}{l}\text { Hypothesized } \\
\text { No. of CE(s) }\end{array}$ & Eigenvalue & $\begin{array}{l}\text { Max-Eigen } \\
\text { Statistic }\end{array}$ & $\begin{array}{l}0.05 \\
\text { Critical Value }\end{array}$ & Prob. ${ }^{*}$ \\
\hline \hline None ${ }^{*}$ & 0.963211 & 89.16915 & 52.36261 & 0.0000 \\
At most $1 *$ & 0.949602 & 80.67075 & 46.23142 & 0.0000 \\
At most 2 $*$ & 0.930711 & 72.07564 & 40.07757 & 0.0000 \\
At most 3* & 0.774582 & 40.22453 & 33.87687 & 0.0077 \\
At most 4 & 0.644631 & 27.93413 & 27.58434 & 0.0451 \\
At most 5 & 0.427526 & 15.06026 & 21.13162 & 0.2847 \\
At most 6 & 0.248101 & 7.699151 & 14.26460 & 0.4101 \\
At most 7* & 0.181931 & 5.421839 & 3.841466 & 0.0199 \\
\hline \hline
\end{tabular}

Max-eigenvalue test indicates 5 cointegrating eqn(s) at the 0.05 level

* denotes rejection of the hypothesis at the 0.05 level

**MacKinnon-Haug-Michelis (1999) p-values

Unrestricted Cointegrating Coefficients (normalized by $b^{\prime * S 11 * b=I): ~}$

Source: Survey result, 2019

\section{The above table indicates that:}

When The trace statics less than the critical value we accept the null hypothesis meaning that at least one co integration equation, and the $\mathrm{p}$ - value greeter than the significance level, so that the $\mathrm{p}$ value at none * less than the significance level we reject the hypothesis at the 0.05 level. Both tables reveals the null hypothesis of no co integration equation is rejected both test at none* While the trace test indicates also one co integration equation at $1 \%$ and $5 \%$. The maximum -Eigen test indicates one co integration equation. That is the null hypothesis of zero co integrated vector is rejected against the alternative of one co integrating vector. The existence of co integrating equation relationships among the (1) variables implies that the determinants of saving mobilization in commercial bank of Ethiopia is More efficiently represented by an error correction specification. 


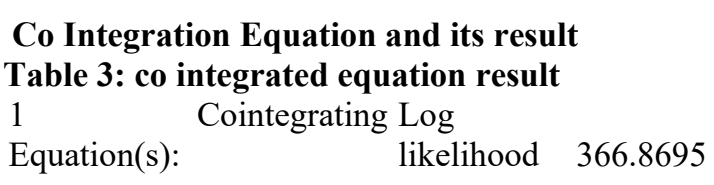

$\begin{array}{lcccccccc}\begin{array}{l}\text { Normalized } \\ \text { parentheses) }\end{array} & \text { cointegrating } & \text { coefficients } & \text { (standard error in } \\ \text { LOG(TD) } & \text { LOG(TI) } & \text { LOG(TE) } & \text { LOG(TA) } & \text { LOG(TL) } & \text { LOG(TR) } & \text { LOG(TLA) LOG(CPI) } \\ 1.000000 & -0.035618 & 0.010839 & -0.569565 & -0.380257 & 0.135655 & -0.170638 & -0.123396 \\ & (0.05194) & (0.01947) & (0.82410) & (0.78478) & (0.04767) & (0.02826) & (0.03599)\end{array}$

Adjustment coefficients (standard error in parentheses)

D(LOG(TD)) - -0.288999

(0.40110)

D(LOG(TI)) $\quad-0.370789$

(0.94908)

D(LOG(TE)) - -1.023135

(1.20405)

$\mathrm{D}(\mathrm{LOG}(\mathrm{TA})) \quad-0.088084$

$(0.53707)$

$\mathrm{D}(\mathrm{LOG}(\mathrm{TL})) \quad 0.007345$

(0.53166)

D(LOG(TR)) - -2.940437

D(LOG(TLA)) 0.438740

$(0.83382)$

D(LOG(CPI)) 1.003347

Normalized

cointegrating

coefficients

(standard error

in parentheses)

$\begin{array}{ccccccc}\text { LOG(TD) } & \text { LOG(TI) } & \text { LOG(TE) } & \text { LOG(TA) } & \text { LOG(TL) } & \text { LOG(TR) } & \text { LOG(TLA) } \\ 1.000000 & -0.035618 & 0.010839 & -0.569565 & -0.380257 & 0.135655 & -0.170638 \\ & (0.05194) & (0.01947) & (0.82410) & (0.78478) & (0.04767) & (0.02826)\end{array}$

Source: Survey result, 2019

Note: since the table is not in the equation form the real sign of coefficients are changed

So, in equation form

$\log (\mathrm{TD})=5.350127+0.035618 \log (\mathrm{TI})-\quad \mathbf{0 . 0 1 0 8 3 9} \log (\mathrm{TE}) \quad+0.569565 \log (\mathrm{TA}) \quad+0.380257 \log (\mathrm{TL})-$ $0.135655 \log (\mathrm{TR})+0.170638 \log (\mathrm{TLA})-\mathbf{0 . 1 2 3 3 9 6} \log (\mathrm{CPI})$ (eq1)

From the above equation is observed that Total Reserve and Consumer price index, negatively affect the Deposit of Commercial Bank of Ethiopia in the long run and result statically significant. Whereas, the Total Income ,Total Asset and Total Loan and Advance affects positively and statically significant in the long run. The estimated parameters of the explanatory variables in the long run:

* The empirical result implies that a percentage increase in the Total income of Commercial Bank of Ethiopia causes 3.5\% increase in Commercial Bank of Ethiopia Deposit that is, it positively affects Commercial Bank of Ethiopia deposit in the long run. That is some amount of the Banks annual income goes to the commercial Bank of Ethiopia deposit that ultimately increase deposit growth of the Bank.

* Expense in Commercial Bank of Ethiopia unlike the total income it negatively affects the Deposit in Commercial Bank of Ethiopia by almost $1 \%$ for a $1 \%$ increase the Total Expense incurred in Commercial Bank of Ethiopia for the given period.

* The above long run equation tells us, the total Asset of the Commercial Bank of Ethiopia positively affects the deposit of the Bank and statically significant in the long run. A percentage increase in the total Asset of Commercial Bank of Ethiopia causes $57 \%$ increase in Commercial Bank of Ethiopia Deposit. that is ,as 
the bank's asset increase, it acquires a public trust and good will to its customers and many people's will be attracted to save their money in the bank because there is no liquidity problem to with draw their money at any time .

* A percentage increase in the total liability of Commercial Bank of Ethiopia causes 38\% increase in Commercial Bank of Ethiopia Deposit. that is, it positively affects Commercial Bank of Ethiopia deposit in the long run. Commercial Bank deposits are major liabilities for commercial banks. Kelvin (2001) said that deposits of commercial banks account for about $75 \%$ of commercial bank liabilities). Due to the fact that commercial banks are using this liability to lend it and gain return on it their deposits are using them do their business.

* $1 \%$ increase in commercial Bank reserve requirement will tend to decrease the total commercial Bank deposit by $13.5 \%$ it is significant and affects negatively commercial Bank of deposit in the long run.

* A percentage increase in the total loans and advance granted in commercial bank causes $17.06 \%$ increase in commercial Bank of Ethiopia Deposit and it affects the deposit growth positively as the CBE granted more loans to those customers. In this regard we can see two basic things: first we can conclude that peoples will be attracted to save their money because of CBE will provide their working capital need and project financing. In order to have a project financing scheme from CBE consumers should fulfill the eligibility criteria of the credit facility. The one that among the edibility criteria is equity contribution so that bankers advices those customers to deposit the minimum requirement. And secondly, while the commercial Bank of Ethiopia grants the loan to its customers the approved amount of loan will directly credited to the customer's account and will have a positive impact in commercial bank of Ethiopia Deposit growth.

* A percentage increase in consumer price index will tend to decrease the commercial Bank of Ethiopia Deposit by $12.3 \%$ it affects negatively the deposit growth of Commercial Bank of Ethiopia and statically significant. In 2012/2013 budget year, the inflation reported by the Ethiopian Statics agency is $23.4 \%$ and Commercial Bank of Ethiopia interest rate is $5 \%$ so that peoples will not attracted to save their money in Commercial Bank of Ethiopia rather they prefer to invest their money to buy the commodities that will appreciate its price the next day.

\section{Vector error correction model (VECM)}

Once the variables are found to be co integrated, we can use vector error correction to determine the short run coefficient. Result has been used to find out the short run dynamics. The results of short run dynamics of the variables are reported in table on annex. According to The error correction term of our short run model is also statistically significant with a negative sign. It is another proof that long run relationship exists among the variables we used in this study. The negative value of coefficient of ECTt-1 indicates the very high speed of convergence towards equilibrium. It may take few years to adjust the equilibrium to be justified and the effectiveness of fiscal policy on real domestic product in Ethiopia and is very sensitive to policy shock.

\section{Conclusions and Recommendations}

\section{Conclusion}

Given the summary result of econometric time series analysis and its trend, the study had concluded the following to commercial banks by taking CBE as evidence of the study. The main source of capital for commercial banks is deposit. Although banks can use other source of funds such as shareholders equity, from the profit of its operation or any other business undertakings the most useful source of capital is deposit.

$>$ In line with the national GTP, Commercial Bank of Ethiopia has designed deposit mobilization strategies and implemented with action plan and have a positive impact on its Deposit growth.

$>$ Among the kind of deposits saving deposits are mostly used by commercial banks and their customers. That is from the deposit available in the bank's the largest proportion is saving deposit which is fixed interest bearing deposit.

$>$ Commercial Bank of Ethiopia can influence the national economy in relation to reduce the money supply only the priority sectors ( Manufacturing, Agriculture and Export) that can impact for enhancing the foreign currency inflow and reducing the foreign currency out flow and ultimately possible to reduce the inflation.

$>$ Since Commercial Bank of Ethiopia is owned by government, it has an opportunity to mobilize government funds through it and an impact positively to take the market share from other private commercial banks so far.

$>$ Commercial banks of Ethiopia can add deposit rate for competition purpose, however the minimum interest rate is fixed by the national bank.

$>$ Service Excellency, good will of the bank, branch expansion, promotional effort, awareness creation and coupon prize can be an opportunities that the bank obtains from its environment and efforts that the bank 
can do to mobilize more deposits.

$>$ The commercial banks can mobilize more deposit when they have convenient office, good transportation access, hard working employees and society who are aware of the banking system.

$>$ Deposit mobilization become more simpler if commercial banks become preferable than other commercial banks and grow their market share.

$>$ Commercial banks incur the following costs to mobilize deposits:-

- Cost of time spent by the banker to mobilize deposit

- Cost of postage and telecommunication

- Cost of time spent by credit analyst to examine loans

- Cost of stationary and office supplies and advertising and publicity cost.

- Administration costs in relation to Branch expansion

- cost of advanced technology so as to more convenient the service for customers.

\section{Recommendations}

Based on the research findings and conclusions the followings are recommended for commercial banks of Ethiopia as a way to mobilize more deposits than before.

The Bank has the responsibility of supporting national development. In view of this, it should play an important role in promoting growth through mobilizing deposits for productive investment, enhancing foreign currency earnings and strengthening loan collection efforts. The developmental role of the Bank includes, among others, financing imports of strategic importance, financing priority sectors and supporting extensive public investment. To accomplish this, the Bank should grow both in expanding its customer base [to mobilize deposits, foreign currency remittances, export earnings, etc] and improving accessibility so that it can generate the required fund to support national development.

So as to Increase Volume of Fund, the Bank should Striving to acquire the necessary fund (both in local and foreign currency) for financing national development. This shall be accomplished by enhanced deposit mobilization, increased foreign currency earnings, and strengthened loan collection efforts. As a result, the CBE can maximize potential for supporting national development.

With the objective of Enhancing Developmental Financing, CBE should Maximizing the Bank's role in national development by ensuring that mobilized resources are channeled to those sectors which can boost economic growth while suppressing inflation (real sectors), such as agriculture, export, and manufacturing. The allocation of credit and FCY to finance investment on infrastructures (e.g. Power plants), priority sector players and import of strategic goods (e.g. fuel).in this regard, CBE can realize its mission of supporting the Nation's Development,

In order to ensure Sustainable Profitability, the CBE should Work on the effectiveness of its efforts towards financing sustainable developmental projects, increasing income and managing operating expenses so that profitability can be guaranteed and ultimately CBE will enhance its role in national development, Strong Financial Position, Sustainable business.

And finally, to ensure Financial Soundness, CBE should aggressively work on the financial health of the Bank through reducing NPL, and adhering to national and international standards of sound financial management (e.g. capital adequacy ratio, Asset and Liability position, NBE's reserve requirement...etc.) and possible to enhance its credibility and goodwill.

\section{Reference}

1. Adam B. Ashcraft (2005). Are Banks Really Special? New Evidence from the FDIC Induced. Failure on Healthy Banks. American Economic Review, PP 1712-17.

2. Allen N. Berger, Asli Demirgüç-Kunt, Ross Levine, Joseph G. Haubrich (2004). Bank Concentration and Competition: An Evolution in the Making. Ohio State University Press, an Evolution in the Making A Conference Sponsored by the Federal Reserve Bank of Cleveland, pp. 433-45.

3. Andy Field (2005). Discovering Statistics Using SPSS. Second edition, Sage publication.

4. Anil K. Kashyap, Raghuram Rajan and Jeremy C. Stein (2002). Banks as Liquidity Providers: An explanation for the Coexistence of Lending and Deposit Taking. The Journal of Finance

5. Brealey Myers (2003). Principle of Corporate Finance. Seventh Edition, the McGraw- Hill Companies.

6. Bruce C. Cohen and George G. Kaufman (1965). Factors Determining Bank Deposit Growth by State: An Empirical Analysis. American finance association, Blackwell publishing, The Journal of Finance, Vol. 20 , No. 1 (Mar., 1965), pp.59-7.

7. Chris Brooks (2008). Introductory Econometrics for Finance. Second edition, Cambridge University Press.

8. Commercial Bank of Ethiopia (2011). Boosting domestic savings in Africa. Mudaye Niway Magazine.

9. Commercial Bank of Ethiopia, Bahir Dar District (2012/13). Assessments of potentials for deposit mobilization under Bahir Dar district 
10. Daniel C. Giedeman (2005). Branch Banking Restriction and Finance Constraints in Early 65, No. Twentieth Century America. Cambridge University Press, the Journal of Economics History, Vol. 1, PP 129-151.

11. Donald R. Hodman (1961). "The Deposit Relationship and Commercial Bank Investment Behavior" The MIT Press, the Review of Economics and Statistics, Vol. 43, No 3, PP 257-268.

12. Dorothee Holl and Andrea Schertler (2009). Why do savings banks transform sight deposits into illiquid assets less intensively than the regulation allows? Discussion Paper.

13. E. A. Shaw (1995). Operational Results of Commercial Banks in Jamaica (1991-1993). Sir Arthur Lewis Institute of Social and Economic Studies, University of the West Indies, Social and Economic Studies, Vol. 44, No. 4, pp 23-40.

14. Erna Rachmawati \& Ekki Syamsulhakim (2004). Factors Affecting Mudaraba Deposits in Indonesia. Working Paper in Economics and Development Studies. Padjadjaran University, Indonesia.

15. Eshetu Bekele \& Mammo Muchie (2009). Promoting Micro Small \& Medium Enterprises (MSMEs) for sustainable rural livelihood. Diiper Research Series, Working Paper No.11, ISS 1902-8679.

16. Eustacius N. Betubiza and David J. Leatham (1995). Factors Affecting Commercial Bank Lending to Agriculture. Southern Agricultural Economics Association.

17. Franklin Allen \& Elena Carletti (2008). The Roles of Banks in Financial Systems. University of Pennsylvania, University of Frankfurt and CFS.

18. G. P. Watkins (1933). "Economics of Saving. American Economic Association" The American Economic Review, Vol. 23, pp. 61-81

19. George G. Kaufman (1972). Deposit Variability and Bank Size. University of Washington School of Business Administration; The journal of financial and quantitative analysis, Vol. 7, No. 5

20. Hamid Rashid (2011). Credit to Private Sector, Interest Spread and Volatility in Credit- Flows: Do Bank Ownership and Deposits Matter? DESA Working Paper No. 105.

21. Harold L. Seligman (1946). The Problem of Excessive Commercial Bank Earnings. Oxford University Press, the Quarterly Journal of Economics, Vol. 60, No. 3, pp. 365 -389.

22. Herald Finger and Heiko Hesse (2009). Lebanon-Determinants of commercial banks Deposits in a Regional Financial Center. IMF Working paper, WP/09/195

23. Ismal, Rifki (2010). The Management of Liquidity Risk in Islamic Banks: The Case Of Indonesia. Doctoral Thesis, Durban University, Available at Durban E-Theses Online: http://etheses.dur.ac.uk/550/

24. Jim Stanford (2008). A "How-To" Guide: Finding and Interpreting GDP Statistics. Canadian Centre for Policy Alternatives.

25. John W. Robinson (2002). Commercial Bank Interest Rate Spreads in Jamaica-Measurement, Trends and Prospects. Bank of Jamaica.

26. Kozo Kiyota, Barbara Peitsch and Robert M. Stern (2007). The Case for Financial Sector Liberalization in Ethiopia. Gerald R. Ford School of Public Policy, University of Michigan.

27. M. A. Baqui Khalily, Richard L. Meyer, Leroy J. Hushak (1987). Deposit Mobilization in Bangladesh: Implications for Rural Financial Institutions and Financial Policies. The Bangladesh Development Studies, Vol. 15, No. 4, pp.85-117

28. M. Shubik and M. J. Sobel(1992). A Problem in Banking and Corporate Finance. INFORMS, Management Science, Vol. 38, No. 6, pp. 827-839

29. Medhat Tarawneh (2004). A Comparison of Financial Performance in the Banking Sector: Some Evidence from Omani Commercial Banks. International Research Journals of Finance and Economics, Euro Journals Publishing.

30. Meenakshi Thyagarajan (1975). Expansion of Commercial Banking: An Assessment. Economic and Political Weekly, Vol. 10, No. 47, PP 1819-1824.

31. Mohammad Namazi and Mahdi Salehi(2010). The Role of Inflation in Financial Repression: Evidence from Iran. IDOSI Publications, World Applied Sciences Journal 11(6): 653-661.

32. Mustafa K. Mujari and Sayera Younus (2009). An Analysis of Interest Rate Spread in Bangladesh. The Bangladesh Development Studies.

33. N. Desinga Rao, 1975. Deposit Mobilization by Co-operative Banks: A Comparison Economic and Political Weekly. No. 29, pp. 1098-1100

34. Peter Mususu (2006).Determinants of Individual and House Hold Saving in Zambia, The Copperbelt University.

35. https://www.combanketh.et/AboutUs/CompanyProfile.aspx

36. Wubitu Elias Gemedu (2012). Factors Determining Commercial Bank Deposit: An Empirical Study on Commercial Bank of Ethiopia.Addis Ababa University 